\title{
GRZEGORZ TRĘicki
}

Uniwersytet Jana Kochanowskiego w Kielcach

\section{WALORY ESTE TYCZNE I EKSPERYMENTY FORMALNE W FANTASY ŚWIA- TA WTÓRNEGO}

Fantasy świata wtórnego ${ }^{1}$ nie bez przyczyny uchodzi w oczach krytyków i literaturoznawców za jeden z najbardziej schematycznych i repetytywnych gatunków współczesnej literatury niemimetycznej. Wydaje się, iż-pomimo niewątpliwego występowania w obrębie SWF dzieł powszechnie uznawanych za wybitne albo przynajmniej ,ambitne” - takich jak, choćby, Władca Pierścieni J. R. R. Tolkiena czy saga Ziemiomorze Ursuli $\mathrm{K}$. Le Guin - jest on w swym całokształcie rządzony raczej przez mechanizmy kulturowe (komercyjne) niźli artystyczne².

Spośród czterech podstawowych walorów czy też funkcji literatury niemimetycznej, jakie wyróżniłem w innym miejscu (Trębicki 2020) - a więc waloru/funkcji fabulacyjno-rozrywkowego, emocjonalno-poznawczego, spekulatywno-ekstrapolatywnego oraz artystyczno-estetycznego najłatwiej dostrzegalny jest w SWF, oczywiście, ten pierwszy.

Tak więc konstytutywnymi elementami struktury typowej powieści SWF, niezależnie od tego że mówimy o tekstach tak różnych twórców jak J. R. R. Tolkien, Robert Howard, Piers Anthony, Norman Gore lub Joe Abercrombie, okazują się przygodowa akcja obfitująca w bitwy magiczne i konwencjonalne, intrygi, pojedynki, romanse, zdrady, etc. oraz wyraziści, choć niekoniecznie wyrafinowani pod względem psychologicznym bohaterowie, z którymi czytelnik mógłby się identyfikować a w każdym razie im kibicować. Do motywów najczęściej „spinających” fabułę i nadających jej bardziej wyrazisty kształt należą zwłaszcza motyw wojny oraz motyw quest - wędrówki której celem jest wypełnienie jakiejś mniej lub bardziej konkretnie zdefiniowanej misji. Fabuła zatem w bardzo wyraźny sposób opiera się na dynamicznych wydarzeniach i jest skonstruowana podług klasycznych schematów, zawierając przejrzyste zawiązanie akcji, rozwinięcie i kulminację; jest też, oczywiście, przedstawiana w sposób chronologiczny.

Warto jednak w tym miejscu zauważyć, że taki a nie inny kształt narracji niekoniecznie musi być motywowany jedynie mechanizmami stricte komercyjnymi. Po części wynika on po prostu z silnego zakorzenienia gatunku we wzorcach mitycznych i baśniowych, które narzucają pewien klasyczny kształt opowieści.

$\mathrm{Na}$ tak skonstruowaną fabułę w ambitniejszych tekstach SWF nadpisane zostają funkcje emocjonalno-poznawcza i (rzadziej) spekulatywno-ekstrapolacyjna czy też intelektualno-poznawcza. Tak więc perypetie bohaterów zaczynają funkcjonować tutaj w obrębie mniej lub bardziej rozbudowanej metaforyki, odwołując się do mitologii,

\footnotetext{
${ }^{1}$ Podobnie jak we wszystkich moich dotychczasowych pracach przez fantasy świata wtórnego rozumiem tutaj pewien ściśle określony, egzomimetyczny gatunek literacki, który konstytuuje się w latach 50-tych dwudziestego wieku w dziełach Tolkiena i jego naśladowców. Jego podstawowe cechy to przede wszystkim: 1. umiejscowienie akcji w stworzonym przez autora świecie wtórnym pseudo-średniowiecznym lub pseudo-starożytnym o niskim stopniu rozwoju technologicznego; 2. powszechne występowanie magii w świecie przedstawionym utworu; 3. Kształtowanie akcji w oparciu m. in. o motywy „magii i miecza” (sword \& sorcery), motyw quest, motywy inicjacji i przemiany duchowej bohatera, motywy walki dobra ze złem oraz motyw w wojny 4 . Względne „zamknięcie” parametrów przestrzennych. Więcej patrz: Trębicki 2007: passim oraz Trębicki 2014: passim. world fantasy").

W dalszej części mojego artykułu będę używał również wymiennie skrótu SWF (od ang. ,secondary

${ }^{2}$ Schematyczność konwencji fantasy była podkreślana, między innymi, przez autorów The Encyclopedia of Fantasy, którzy wydają się wręcz sugerować, że artystyczna wtórność jest niejako immamentnie wpisana w poetykę gatunku (396). Powtarzalność fabuł typowej epickiej fantasy wyśmiewał z kolei Andrzej Sapkowski (1993). Pośledność fantasy w relacji względem SF z kolei krytykowali Darko Suvin (1973, 1999-2001 oraz 2006) a także Stanisław Lem (1983). Krótkiego podsumowania sporu pomiędzy zwolennikami SF a fantasy dokonuję w: Trębicki 2019.
} 
archetypów, rytów przejścia, religii czy też współczesnej filozofii, etyki i psychologii. Jako przykłady można podać dzieła J. R. R. Tolkiena, Ursuli K. Le Guin, Stephena Donaldsona, Tanith Lee a z polskiej SWF - Anny Borkowskiej (Gar'ingawi Wyspa Szczęśliwa) oraz Andrzeja Sapkowskiego i Roberta M. Wegnera.

Kwestie związane z występowaniem w fantasy elementów opisanych powyżej oraz głębszych struktur znaczeniowych, a także obecności w niej (lub jej braku) jakkolwiek zdefiniowanych walorów poznawczych były już przedmiotem wielu interesujących analiz oraz polemik ${ }^{3}$. W tym miejscu chciałbym się zatem skoncentrować na ostatnim z zaproponowanych przeze mnie walorów/funkcji, to jest na walorze artystyczno-estetycznym, któremu jak dotąd poświęcono chyba najmniej uwagi.

Zanim jednak rozpocznę właściwą dyskusję, celem zminimalizowania potencjalnych nieporozumień, spróbuję uściślić analizowane zjawisko i w sposób możliwie jasny określić zakres analizowanego materiału tekstowego. Po pierwsze, chciałbym więc jeszcze raz mocno podkreślić, iż przedmiotem mojego zainteresowania będą wyłącznie dzieła SWF, czyli stosunkowo wąsko rozumianej fantasy. Terminem fantasy, jak wiemy, potocznie określa się bardzo szerokie spektrum tekstów, obejmujące również pozycje i gatunki ${ }^{4}$ i reprezentujące (z punktu widzenia używanej przeze mnie metodologii) obok supragenologicznej kategorii literatury egzomimetycznej również kategorie literatury antymimetycznej i fantastycznej; teksty często wbrew pozornym podobieństwom (występowanie magii) posługujące się znacząco odmiennym zestawem konwencji. Oczywiście, poszerzenie materiału w pewnym sensie ułatwiłoby moje zadanie - twórczość pisarzy takich jak Neil Gaiman, China Mieville, Steph Swainston, Susannah Clarke czy Catherine M. Valente, pełna różnorakich innowacji i eksperymentów, co i rusz frustrująca oczekiwania przeciętnego czytelnika, stanowiłaby znacznie wdzięczniejszy obiekt badań. Mnie jednak, jak już zaznaczyłem na początku niniejszego artykułu, interesuje w tym momencie możliwość zaistnienia specyficznie zdefiniowanych walorów estetycznych w obrębie względnie schematycznych i ograniczających konwencji SWF właśnie.

Po drugie, czuję się też zobligowany doprecyzować, co właściwie mam na myśli mówiąc o walorach artystyczno-estetycznych, zwłaszcza że samo pojęcie w większości powszechnie funkcjonujących znaczeń, zarówno tych potocznych jak i obecnych na gruncie krytyki literackiej, estetyki czy teorii literatury, jest przedmiotem różnorakich sporów i kontrowersji. Nie jest jednak moim celem w tym miejscu dołączać do tej skądinąd fascynującej, tyleż teoretyczno-metodologicznej co również chyba ideologicznej dyskusji, ani wykraczać poza kontekst prezentowanej przeze mnie analizy, tak jak swój zamiar zakreśliłem uprzednio. Opisując walory czy też funkcję artystyczno-estetyczną w literaturze niemimetycznej skoncentruję się zatem na tych elementach struktury tekstów (przede wszystkim na języku utworów oraz kompozycji), które nie służą w wyraźny sposób wyrażaniu i wzmacnianiu pozostałych trzech funkcji - a więc rozrywkowo-ludycznej, emocjonalno-poznawczej i spekulatywno-ekstrapolacyjnej (intelektualno-poznawczej), lecz mają charakter względnie autoreferencyjny.

Pojawienie się tak rozumianej funkcji estetycznej stanowiłoby zatem, w pewnym sensie, dewiację wobec panujących w SWF schematów, które przypisują językowi i kompozycji rolę zdecydowanie służebną. Na początek przyjrzyjmy się więc, jak prezentują się powyższe schematy (w koniecznym uproszczeniu i uogólnieniu).

${ }^{3}$ Patrz, choćby, Attebery 1992: passim; Godshalk 1975: 149-55; Le Guin 1982: 49-61; Oziewicz 2008: passim; Raffael 1968: 218-246 oraz Scholes 1975: passim.

${ }^{4}$ Niektóre takie gatunki - jak choćby „współczesna powieść magiczna” (contemporary magical novel) czy „współczesna fantasy metaforyczna” (the contemporary metaphorical fantastic novel) wstępnie rozpoznaję i opisuję w: Trębicki 2015. 
Jeśli chodzi o kompozycję, to jak już zauważyłem wcześniej, dzieła SWF w zasadzie bez wyjątku odwołują się do klasycznej, zamkniętej kompozycji ${ }^{5}$, z chronologicznie prowadzoną fabułą, o wyraźnym zawiązaniu akcji, jej rozwinięciu, stosownej kulminacji i rozwiązaniu. Narrator w starszych dziełach SWF (do lat 80-tych) często bywa trzecioosobowy i wszechwiedzący, w nowszej SWF przeważa natomiast trzecioosobowy o ograniczonym punkcie widzenia, opowiadający konkretną scenę z pozycji określonej postaci ${ }^{6}$. Stosunkowo rzadko pojawia się narrator pierwszoosobowy o ograniczonym punkcie widzenia ${ }^{7}$. Nowsze dzieła SWF (mam tu na myśli przede wszystkim epicką powieść rzekę, którą opisałem w innym miejscu ${ }^{8}$ ) charakteryzują się, rzecz jasna, znacznym stopniem fabularnej komplikacji i wielowątkowością, odmiennymi strategiami konstrukcji bohaterów niż w bardziej klasycznej SWF w stylu Tolkiena czy Le Guin, ale nie oznacza to bynajmniej przełamania wspomnianych powyżej tradycyjnych konwencji.

W kwestii języka da się zauważyć trzy najczęściej spotykane operacje. Po pierwsze, jego archaizacja, przede wszystkim w starszych dziełach klasycznej epickiej fantasy (oprócz Tolkiena dostrzec ją można również bardzo wyraźnie w np. Kronikach Thomasa Covenanta, Niedowiarka Stephena R. Donaldsona). Ma ona przede wszystkim na celu wprowadzenie podniosłego nastroju oraz nawiązanie do tradycji mitu, eposu bohaterskiego czy romansu rycerskiego (choć, na przykład, w Sadze o Wiedźminie Andrzeja Sapkowskiego staropolska „rubaszna” stylizacja pełni chyba przede wszystkim funkcję ludyczną). Po drugie, w większości dzieł fantasy widoczna jest tendencja do przejrzystości i względnej jednoznaczności języka, co niekiedy (w tekstach mniej ambitnych) jest związane $\mathrm{z}$ dostosowaniem form ekspresji językowej do oczekiwań mniej wyrobionego, masowego odbiorcy, a czasem (w tekstach z ,górnej półki” SWF) ma na celu precyzyjne przekazanie określonych znaczeń. Zaznaczyć tu jednak od razu trzeba, że prostota ta bywa bardzo kunsztowna (jak choćby u Ursuli K. Le Guin) i dzięki zastosowanej ekonomii i starannemu dobraniu środków wyrazu nie pozbawiona jakości estetycznej a nawet swoistej poetyckości. Po trzecie, zwłaszcza w najnowszej fantasy, zaznacza się tendencja (w dużej mierze przeciwstawna do pierwszej z wymienionych powyżej) do wulgaryzacji i dosadności języka, co wydaje się zabiegiem typowo komercyjnym, obliczonym na zjednanie wychowanego przez współczesną popkulturę czytelnika.

W tym miejscu warto chyba wspomnieć o jeszcze jednym zjawisku. Wszystkie niemal bez wyjątku dzieła SWF, reprezentujące różne jej odmiany i etapy ewolucji, dążą do względnej jednoznaczności przekazu, to jest unikają niedopowiedzenia jako środka artystycznego wyrazu. Dotyczy to zarówno sfery „faktograficznej”, czyli tego, co się w utworze wydarza, jak i wewnątrztekstowej interpretacji tychże zdarzeń ${ }^{9}$. Tak wiec czytelnik fantasy może oczekiwać, iż niezależnie od tego, jak bardzo tajemniczy wydaje się na początku świat przedstawiony i jak bardzo zagmatwane intrygi, w które zostali wplątani bohaterowie, wszystkie kluczowe elementy zarówno fabuły jak i tekstowej rzeczywistości przed końcem lektury zostaną wyjaśnione, zracjonalizowane i uporządkowane przez autora implikowanego (a nierzadko i opatrzone mniej lub bardziej subtelnym i zawoalowanym komentarzem). Oczywiście - z przyczyn czysto technicznych - owo

\footnotetext{
${ }^{5}$ Jako rzadki stosunkowo przykład dzieła o kompozycji ramowej można podać Kroniki Królobójcy Patricka Rothfussa.

${ }^{6} \mathrm{~W}$ przypadku najnowszej epickiej powieści rzeki fantasy - tekstów Roberta Jordana, Stevena Eriksona czy George’a R. R. Martina mamy do czynienia z ogromną ilością takich głosów narracyjnych, przyczyniających się do prezentacji rozległej, epickiej panoramy świata przedstawionego.

${ }^{7}$ Na przykład Rok Jednorożca Andre Norton.

${ }^{8}$ Patrz: Trębicki 2007: 105-117.

${ }^{9}$ Farah Mendlesohn dokonuje ciekawej obserwacji, dotyczącej klasy tekstów określonej przez nią jako „,portal-quest fantasy” (zasadniczo tożsamej z tym co w ramach niniejszego artykułu określam jako SWF). Badaczka zauważa, że forma ta wydaje się narzucać pewną autorytarną, ,jedynie słuszną" interpretację fikcyjnego uniwersum i znacząco zawęża potencjalne możliwości narracyjne. Patrz: Mendlesohn 2007: XX oraz 1-58 oraz moje omówienie tejże w: Trębicki, 2014a.
} 
„wyjaśnienie” świata i fabuły może zostać znacząco odroczone czy też częściowo zaniechane bądź wyegzekwowane nieumiejętnie (mam tu na myśli zwłaszcza nieustannie rosnącą objętość i komplikację współczesnych sag SWF; niekiedy można wręcz odnieść wrażenie, że autorzy zaczynają tracić już kontrolę nad swymi powieściowymi światami i fabułami), ale powstałych w ten sposób niedopowiedzeń nie można raczej traktować jako świadomego zabiegu artystycznego ${ }^{10}$. To samo dotyczy sfery przesłań i znaczeń nawet twórcy SWF uchodzący za najambitniejszych, których dzieła prezentują w powszechnym mniemaniu najwyższy poziom artystyczny - starają się uczynić swój przekaz względnie jednoznacznym i zamkniętym, wbrew pozorom nie pozostawiając wiele osądowi i wyobraźni czytelnika ${ }^{11}$.

Chcąc uniknąć nieporozumień - o które przecież nietrudno wobec rozmaitych rozbieżności i kontrowersji dotyczących definicji samego pojęcia „wartości artystyczne” - jeszcze raz chciałbym pokreślić pewną kluczową kwestię. Z tego, co napisałem powyżej, mogłoby się wydawać, iż wbrew opiniom wielu uznanych krytyków czy literaturoznawców odmawiam Władcy Pierścieni Tolkiena czy Ziemiomorzu Le Guin wartości artystycznych, co, oczywiście, byłoby absurdem. Jeśli jednak przyjmiemy takie rozumienie poszczególnych walorów, jakie przedstawiłem na wstępie, to wówczas okaże się, iż ranga tych tekstów wydaje się wynikać przede wszystkim z ich wartości emocjonalno-poznawczych (i w mniejszym stopniu, w przypadku Ursuli K. Le Guin również spekulatywno-ekstrapolacyjnych). Nie negując bynajmniej występowania w powyższych dziełach swoistej „literackości”, a nawet jakości poetyckiej ${ }^{12}$, zwracam jednak uwagę, iż nie mają one tutaj charakteru w pełni autonomicznego, lecz wzmacniają przekaz funkcji poznawczych. Kompozycyjnie powieści te stanowią też zbiór bardzo tradycyjnych konwencji, unikając jakichkolwiek innowacji czy eksperymentów. Upraszczając zatem - sposób opowiadania historii jest wyraźnie służebny wobec jej przesłania i innych elementów struktury tekstów. Nie stanowi - sam w sobie - dominanty utworu.

Zasadne staje się zatem w tym momencie pytanie, gdzie leży przyczyna owej, jak się wydaje, wybijającej się nawet na tle innych gatunków współczesnej popularnej prozy niemimetycznej formalnej schematyczności i zachowawczości? W przypadku tekstów typowo komercyjnych odpowiedź wydaje się względnie prosta - wynika ona, oczywiście, z mechanizmów rynkowych, z oczekiwań wydawcy i przeciętnego odbiorcy. Jeśli chodzi natomiast o dzieła ambitniejsze, to można chyba postawić tezę, iż schematyczność, o której pisałem powyżej, jest spowodowana bardzo mocnym (i głębokim) osadzeniem SWF w strukturach mitu, eposu heroicznego, rytów przejścia, baśni. Być może zachowanie tych struktur i ukrytych w nich archetypów i znaczeń, innymi słowy, stworzenie ontologicznie, etycznie i emocjonalnie relewantnej opowieści, narzuca też zastosowanie określonych konwencji formalnych. Tezę tę mogłaby potwierdzać obserwacja, iż utwory

\footnotetext{
${ }^{10}$ Wydaje się, że właśnie coś takiego przydarzyło się Andrzejowi Sapkowskiemu w samym zakończeniu jego „Sagi o Wiedźminie”.

${ }^{11}$ Przyjrzyjmy się, choćby, następującym narratorskim komentarzom: „Teraz, gdy widział przyjaciela i słyszał jego słowa, wątpliwości znikły. I Vetch zaczynał rozumieć prawdę: Ged ani nie został pokonany, ani nie zwyciężył, lecz nazywając cień swej Śmierci swoim własnym imieniem, uczynił siebie całością: człowiekiem; kimś, kto znając swojo całe, prawdziwe ja, nie może zostać wykorzystany ani zawładnięty przez żadną inną moc poza samym sobą, i kto przeżywa dzięki temu swoje życie w imię życia, a nigdy w służbie zniszczenia, cierpienia, nienawiści lub ciemności” (Le Guin 1991: 152) lub „Barbayat, przeglądając w swoim krysztale przeszłość Volka, nie pominęła niczego, a Shaina okazała się pojętną uczennicą [...]. To nienawiść jest logiczna, to nienawiść tworzy prawa. Miłość ich nie potrzebuje, miłość wie [...] Moc czarnego boga była złamana, pokonana. Nigdy już nie miała powrócić, gdyż odmieniła ją miłość, miłość równie silna jak nienawiść, równie bezwzględna i nieugięta. To miłość sprawiła, ze moc z czarnej stała się biała, jak biały stał się posąg” (Lee 1991: 164-165). W powyższych fragmentach uderza autorytatywność i wszechwiedza narratora, pragnącego najwyraźniej by w głowie czytelnika nie pozostały żadne wątpliwości co do dokładnego przebiegu i etycznego znaczenia prezentowanych wydarzeń.

${ }_{12}$ Patrz, na przykład, omówienie aspektu lirycznego Władcy Pierścieni w: Zgorzelski 1975.
} 
otwarcie hybrydalne, których autorzy dążą do bardziej radykalnych eksperymentów tracą wspomnianą relewancję, mimo, iż świat przedstawiony w dużej mierze tworzony jest według prawideł SWF (jako doskonały przykład mógłby tu chyba posłużyć Rok naszej wojny Steph Swainston jak i wiele innych dzieł fantasy imersyjnej ${ }^{13}$ ).

Po tak przeprowadzonym rozpoznaniu spróbuję sformułować problem badawczy w sposób następujący: czy i na ile możliwe są teksty SWF, w których, z jednej strony, walor estetyczno-artystyczny we względnie wyraźny sposób stanowi dominantę, z drugiej strony zaś zachowana zostaje opisana wcześniej, charakterystyczna dla dojrzałych dzieł gatunku relewancja ontologiczna etyczna i emocjonalna. Ponadto można uznać, iż teksty te zasadniczo mieszczą się w obrębie przywołanego uprzednio opisu SWF (a nie należałoby je raczej zakwalifikować jako teksty hybrydalne).

W dalszej części artykułu pokrótce omówię dwa teksty, które - jak się zdaje spełniają powyższe warunki.

Pierwszym z nich jest trzyczęściowa powieść Patrycji McKillip Mistrz zagadek $z$ Hed. Na pierwszy rzut oka dzieło to stanowi kombinację dość typowych dla tego okresu konwencji fantasy epickiej oraz fantasy inicjacji przemiany duchowej, nawiązując z jednej strony do Tolkiena (walka dobra ze złem, ostateczna bitwa, w której rozstrzygają się losy świata) z drugiej do Ursuli Le Guin czy Andre Norton (koncentracja na motywie przemiany duchowej bohatera). Tak więc protagonista, młody książę Hed, Morgon, w znacznym stopniu stanowi kolejną wersję Arrena czy Arragorna: książę posiada ukryte moce i wielkie (aczkolwiek na początku bardzo niejasne) przeznaczenie dzięki czemu skutecznie rozstrzyga wojnę ze złowrogimi i tajemniczymi Zmiennokształtnymi i przywraca równowagę Krainie Najwyższego (Trębicki 2014b: 55-56). Dość nietypowy jest jednak sam sposób opowiedzenia historii.

Po pierwsze, mamy tu do czynienia z czymś, co w innym miejscu nazwałem ,poetyką zagadek". Tak więc

Quest Morgona od początku zostaje zdefiniowany przez zagadki, które protagonista musi rozwiązać, aby z powodzeniem go ukończyć. Wszystko wydaje się niejasne aż do prawie samego końca powieści: Morgon nie zdaje sobie sprawy z ważności swojej misji ani z własnej prawdziwej natury, nie wie, kim są jego wrogowie, co oznaczają trzy gwiazdki na jego czole, kto i dlaczego nastaje na jego życie (i, być może, na pokój całej krainy), jak również, kto prowadzi go i mu pomaga. Nawet tożsamość niektórych pierwszoplanowych postaci nie jest oczywista, jako że wiele z nich okazuje się być ostatecznie kimś zupełnie innym, niż zdawało się na początku. Sojusznicy nieoczekiwanie stają się wrogami, a zdrajcy - przewodnikami. Tożsamość Najwyższego, dobroczynnego strażnika krainy, zostaje przejęta przez zdradzieckiego czarodzieja, Ghisteslwchlohma, zaś za maską jego sługi, harfisty Detha skrywa się z kolei sam Najwyższy. Nawet strategie narracyjne pomagają stworzyć napięcie i przyczyniają się do wzmocnienia tej szczególnej „poetyki zagadek”. Na przykład w drugim tomie narzeczona Morgona, Raederle, zastępuje go jako postać prowadząca, i czytelnik wraz z Raederle zostaje skonfrontowany z zagadką, co naprawdę przytrafiło się Morgonowi na górze Erlenstar. Tak więc motywy inicjacji i przemiany protagonisty służą kreacji pewnej gry literackiej (Trębicki 2014b: 55-56) ${ }^{14}$.

Zaznaczyć tutaj trzeba, iż nie chodzi tu jedynie o ilość i stopień komplikacji intryg, lecz o sposób ich przedstawienia: oniryczny, unikający dosłowności, epatujący tajemniczością i niedopowiedzeniami. Dobrze ilustruje to scena, w której Morgon, błąkając się w podziemiach pod górą Isig, natrafia na starożytną komnatę, gdzie spotyka widmowe dzieci:

- Jesteś dzieckiem - wyszeptał Morgon, wpatrując się w nieruchomą, zielonkawoszarą twarz. Jasna główka uniosła się, spojrzały na niego białe jak gwiazdy oczy.

\footnotetext{
${ }^{13}$ Termin zaproponowany przez Farah Mendlesohn (2008: xx-xi oraz 59-113).

${ }^{14}$ Por. Sapkowski 1999: 8-9.
} 
- Jesteśmy dziećmi - to był ten sam głos, głos dziecka - czysty, senny.

- Wszyscy jesteśmy dziećmi, dziećmi Panów Ziemi [...] Staliśmy się kamieniem w kamieniu. Ziemia nas ujarzmiła.

Morgon uniósł wyżej pochodnię. Wszędzie wokół powstawały z cieni jasne, widmowe postaci dzieci. Przypatrywały mu się ciekawie, bez lęku, jakby widziały w nim postać ze swych snów [...]

- Jak długo... jak długo tu jesteście?

- Od wojny.

- Od wojny?

- Tej sprzed Osadnictwa. Czekałyśmy na ciebie. Obudziłeś nas [...] Masz gwiazdki. - Drobna rączka uniosła się i dotknęła czoła Morgona. - Trzy za życie, trzy za wiatry i trzy za... - chłopiec dźwignął w górę miecz, który trzymał, i podał go Morgonowi wysadzaną gwiazdkami rękojeścią naprzód - ... śmierć. Tak nam obiecano.

Morgon przełknął te słowa jak gorzka pigułkę; ujął miecz za ostrze.

- Kto wam obiecał?

Ziemia. Wiatr. Wielka wojna nas zniszczyła. Obiecano nam więc człowieka pokoju.

- Rozumiem - głos mu drżał. - Rozumiem. - Przykucnął przed chłopcem. - Jak masz na imię?

Chłopiec milczał przez chwilę, jakby miał trudności ze znalezieniem odpowiedzi. Nieruchome rysy jego twarzy znowu drgnęły.

- Miałem... miałem na imię Tirnon - powiedział, zacinając się. - Moim ojcem był Tir, Pan Ziemi i Wiatru.

- Ja miałam na imię Ilona - odezwała się mała dziewczynka [...] Moją matką była... moją matką była... [...]

Tłoczyły się wokół Morgona, nie zważając na ogień, ich głosy były beztroskie, senne. Pozwalał im mówić, obserwując niewiarygodnie delikatne, pozbawione życia buzie.

- Co się stało? - wyrzucił z siebie w pewnej chwili, przekrzykując dziecięcy gwar. - Dlaczego tu jesteście?

Ucichly.

- Zniszczyli nas - powiedział obojętnie Tristan.

- Kto?

Ci z morza. Edolen. Sec. Zniszczyli nas i nie mogłyśmy już żyć na ziemi; nie mogłyśmy jej ujarzmiać. Mój ojciec ukrył nas tu przed wojną. Znaleźliśmy miejsce do umierania (McKillip 1999: 251253).

W powyższej scenie Morgon zostaje skonfrontowany z mityczną, zapomnianą przeszłością swego świata, która ma jednak wpływ na jego własne przeznaczenie. Otrzymuje jednak od dzieci (a wraz z nim czytelnik) jedynie strzępy informacji. I w dużej mierze (scena ma miejsce w pierwszym tomie) fragmenty te pozostaną fragmentami aż do samego końca powieści. Owszem, później dowiemy się, że ojciec Tirnona był w istocie Najwyższy, ale nie poznamy żadnych dodatkowych szczegółów dotyczących losu jego $\mathrm{i}$ innych dzieci czy też faktycznego przebiegu wojny sprzed tysięcy lat, a postacie mitycznych antagonistów, Edolen i Sec, nigdy nie zostaną w pełni zidentyfikowane - Zmiennokształtni aż do samego końca zachowają wiele ze swej enigmatyczności. Sytuacja ta dotyczy nie tylko spraw - z punktu widzenia Morgona - stanowiących zamierzchłą przeszłość, ale i całego świata przedstawionego. Wiele spośród występujących w powieści postaci - na przykład władcy Har i Danan, sojusznicy Morgona, również pozostaną postaciami zagadkowymi. W przeciwieństwie do ogromnej większości powieści SWF od Tolkiena czy Howarda począwszy, a na Eriksonie, Jordanie czy Martinie skończywszy, których twórcy dążą do wyczerpującego objaśnienia i uszczegółowienia powieściowego świata, utwór McKillip mnóstwo rzeczy pozostawia wyobraźni czytelnika, tworząc przestrzeń dla bardziej metaforycznego, wręcz „poetyckiego" odbioru. Tak więc „poetyka zagadek” łączy się tutaj z ,poetyką niedopowiedzeń”.

Oczywiście, wymienione zjawiska są też ściśle powiązane z określonym użyciem języka, bardzo artystycznego, operującego metaforą, niekiedy tak wieloznacznego jak sama fabuła i postacie Trębicki 2014b: 56). Przyjrzyjmy się, dla przykładu, opisowi ostatecznej konfrontacji Morgona ze Zmiennokształtnymi: 
Morgon ruszył przez Wichrową Równinę. Szła za nim armia umarłych Panów Ziemi; rozlewali się po Ymris, szukali żyjących Panów Ziemi, by zakończyć tę wojnę. Wiatry wypłaszały Panów Ziemi spod postaci kamieni i liści, w których się ukryli; umarli wypierali ich z milczącym zdecydowaniem z krainy, którą niegdyś tak kochali. Rozproszyli się po bezdrożach, po wilgotnych, mrocznych kniejach, po nagich wzgórzach, po lodowatych taflach lungoldzkich jezior. Morgon, poprzedzany przez wiatry, postępując na czele umarłych, ścigał ich aż na próg zimy. Ścigał ich z taką samą nieustępliwością, z jaką oni gnali go kiedyś do Góry Erlenstar.

Kiedy spychał ich pod górę, po raz ostatni spróbowali stawić mu czoło. Ale natrafili na mur umarłych, a z góry runęły na nich wściekłe wiatry. Mógł ich wtedy zniszczyć, odrzeć z mocy, tak jak oni próbowali uczynić to jemu. Ale coś z ich piękna tliło się nadal w Raederle, i to coś podpowiadało mu, jacy niegdyś byli; i nie miał serca ich zabijać. Nie tknął nawet ich mocy. Zepchnął wszystkich pod Górę Erlenstar, gdzie ukryli się przed nim w kształtach wody i klejnotów. Zapieczętował całą górę - wszystkie korytarze i ukryte źródła, zewnętrzne stoki i skalne korzenie — swoim imieniem. Pośród drzew i głazów wokół góry, w świetle i na wietrze, postawił na straży umarłych. Potem uwolnił wiatry od swojej pieśni, a one ściągnęły na całe królestwo zimę z północnych rubieży (McKillip 1999: 290-291).

Podobne w swej istocie operacje zostały również zastosowane w powieści Petera S. Beagle’a Pieśń oberżysty z 1993 r. Podobnie jak powieść McKillip dzieło to wydaje się wykorzystywać typowe dla klasycznej SWF konwencje. Widać tu zwłaszcza wyraźnie inspiracje Ziemiomorzem Le Guin. Potężny czarodziej, bezimienny nauczyciel Lal i Soukyana pod wieloma względami przypomina „późnego” Geda, podczas gdy jego były uczeń Arshadin, zaś główny antagonista tekstu - Coba, przeciwnika Geda z Najdalszego brzegu. Nawet upiorny gebbeth z Czarnoksiężnika... odnajduje swój odpowiednik w niemniej potwornym grigaacie z powieści Beagle’a (Trębicki 2014b: 85-86). Występuje tu również wiele innych, ,stockowych" motywów SWF - ukradzione tożsamości, magiczne pojedynki, postaci zmiennokształtnych, najemnych zabójców, wojowników, pieśniarzy, umarłych przywróconych do życia, dzielnych młodzieńców, etc. Jeśli zatem spojrzymy na fabułę i konstrukcję świata przedstawionego w sposób czysto „faktograficzny”, dzieło Beagle sprawia wrażenie wtórnego.

A jednak takim nie jest. Znów, tak jak w przypadku Mistrza Zagadek z Hed, wynika to z samego sposobu przedstawienia opowieści. Głównym atutem tekstu, który wyróżnia go spośród setek innych powieści fantasy, jest w tym przypadku unikalna struktura narracji. W tekście wprowadzono bowiem wielość subiektywnych narratorów pierwszoosobowych, na zmianę relacjonujących historię z ograniczonego punktu widzenia określonej postaci. Utwór podzielony został na rozdziały, których tytuły identyfikują opowiadającego - na przykład „Lal”, „Soukyan”, „Tikat” czy „Rosseth. Zabieg ten czyni akcję bardziej dynamiczną, ale też wprowadza operowanie niedopowiedzeniem jako istotnym elementem narracji. Wiedza poszczególnych bohaterów - a więc i czytelnika nigdy nie jest pełna i zmusza odbiorcę do bardziej aktywnego rekonstruowania historii. Co znamienne, narracja nigdy nie zostaje powierzona dwóm najlepiej poinformowanym postaciom, a więc staremu czarodziejowi i Arshardinowi. Świat przedstawiony, podobnie jak w przypadku Mistrza zagadek, choć plastyczny i egzotyczny, pozostaje w dużej mierze niedopowiedziany, mglisty, wieloznaczny.

Oba zaprezentowane powyżej teksty spełniają podstawowy warunek określony na początku niniejszego artykułu, mianowicie funkcje estetyczno-artystyczne, sam sposób prowadzenia narracji oraz specyficzne użycie języka stanowią tu niewątpliwą dominantę, porządkującą pozostałe funkcje (rozrywkowo-fabulacyjną, emocjonalno-poznawczą, w najmniejszym chyba stopniu spekulatywno-ekstrapolacyjną). Ich potencjalna wartość w odbiorze docelowego czytelnika również wydaje się bazować przede wszystkim na aspekcie formalnym - gdyby opowieści te przedstawiono w bardziej konwencjonalny sposób, zostałyby one w znacznej mierze zredukowane do względnie schematycznych 
i wtórnych konwencji i utraciły swój niewątpliwy wysoki status. Jednocześnie dzięki wykorzystaniu klasycznych motywów i ich stosunkowo poważnemu, ambitnemu potraktowaniu, skutkującemu zachowaniem charakterystycznej dla dojrzałych dzieł SWF relewancji ontologicznej, etycznej i emocjonalnej, mieszczą się też z pewnością w najbardziej nawet ortodoksyjnie zakreślonych ramach gatunku. Warto też zwrócić uwagę, że innowacje artystyczne nie przekraczają pewnej umownej granicy, za którą nastąpiłby chyba nieunikniony kolaps funkcji fabulacyjno-rozrywkowej oraz emocjonalno-poznawczej czy też, innymi słowy, „dekonstrukcja” tradycyjnie pojmowanej opowieści.

Reasumując, zaprezentowane teksty udowadniają, iż pojawienie się znaczących innowacji formalnych oraz uzyskanie przez funkcję artystyczno-estetyczną pozycji strukturalnej dominanty jest możliwe nawet w obrębie stosunkowo schematycznego gatunku literackiego, jakim jest współczesna SWF. Z drugiej strony, trzeba jednak zauważyć, iż opisany powyżej trend nigdy nie odegrał znaczącej roli w ewolucji SWF - a patrząc już z typowo kulturowego punktu widzenia, nie zyskał sobie większej popularności wśród autorów, wydawców i czytelników i jest, można by rzec, statystycznie nieistotny. Piszącemu te słowa trudno byłoby też wskazać większą ilość tekstów, zwłaszcza nowszych (może poza kolejnymi powieściami Patrycji McKillip), które w sposób wyraźny go kontynuują. Ewolucja współczesnej fantasy wydaje się zmierzać w zupełnie innych kierunkach, co jednak już przekracza tematykę zakreśloną w ramach niniejszego omówienia.

\section{Bibliografia}

Attebery, B. (1992). Strategies of Fantasy. Bloomington and Indianapolis: Indiana University Press.

Beagle, P. S. (1991). Pieśń oberżysty (tłum. Ł. Nicpan). Warszawa: Alfa.

Godshalk, W. L. (1975). Alfred Bester: Science Fiction or Fantasy. "Extrapolation 16.2”, 149-55.

LEe, T. (1991). Czarnoksiężnik z Volkyanu (tłum. Danuta Górska). Warszawa: Wydawnictwo Alfa.

LE GuIn, U. K. (1982). The Child and the Shadow. W: The Language of the Night. Essays on Fantasy and Science Fiction (s. 49-61). New York: Berkley Books.

Le Guin, U. K. (1991). Czarnoksiężnik z Archipelagu (tłum. S. Barańczak). Gdańsk: Phantom Press.

Lem, S. (1983). Postowie do: Ursula K. Le Guin, Czarnoksiężnik z Archipelagu (s. 191198). Kraków: Wydawnictwo Literackie.

Mendlesohn, F. (2008). Rhetorics of Fantasy. Middletown, Connecticut: Wesleyan University Press.

McKillip, P. A. (1999). Mistrz zagadek z Hed (thum. J. Manicki). Warszawa: Mag.

Oziewicz, M. (2008). One Earth, One People. The Mythopeic Fantasy Series of Ursula K. Le Guin, Lloyd Alexander, Madeleine L'Engle and Orson Scott Car. Jefferson, North Carolina, and London: McFarland \& Company, Inc., Publishers.

RAFFAEL, B. (1968). The Lord of the Rings as Literature. W: N. D. Isaacs I R. A. Zimbardo (red.), Tolkien and the Critics (s. 218-246). Notre Dame: U. of Notre Dame Press.

Sapkowski, A. (1993). Piróg albo nie ma złota w Szarych Górach. „Nowa Fantastyka”, nr 5, 65-72.

SAPKowsKi, A. (1999). Złotooki potwór wyobraźni. Wstęp do: P. A. McKillip, Mistrz zagadek z Hed (s. 6-15). Warszawa: Mag. 
Scholes, R. (1975). Structural Fabulation: An Essay on the Future of Fiction. South Bend, IN: U of Notre Dame Press.

Suvin, D. (1973). Science Fiction and the Genological Jungle. "Genre 6.3", 251-273.

Suvin, D. (1999-2001). Considering the Sense of 'Fantasy' or "Fantastic Fiction": an Effusion. Academia.edu. - Share Research. https://www.academia.edu/14688975/CONSIDERING_THE_SENSE_OF_FANTASY_OR_FANTASTIC_FICTION_AN_EFFUSION_1999-2001_21_780_words

Suvin, D. (2006). On Ursula K. Le Guin's "Second Earthsea Trilogy" and its Cognitions: A Commentary. "Extrapolation 47.3". Pozyskano z: Findarticles.com.

The Encyclopedia of Fantasy (1999). Red. Clute and J. Grant. New York: St. Martin's Press.

TręBICKI, G. (2007). Fantasy. Ewolucja gatunku. Kraków: Universitas.

TRĘBICKI, G. (2014a). Narratologiczna taksonomia fantasy: propozycje teoretycznoliterackie Farah Mendlesohn. „Zagadnienia Rodzajów Literackich”, t. LVII, zeszyt 1 (113), 107-117.

TręBICKI, G. (2014b). Synkretyzm fantasy. Fantasy świata wtórnego: literatura, kultura, mit. Kraków: Libron.

TręBicki, G. (2015). Worlds so Strange and Diverse. Towards a Genological Taxonomy of Non-mimetic Literature. Newcastle Upon Tyne: Cambridge Scholars Publishing.

TręвICKI, G. (2019). Debate On The Merits Of Fantastic Literature. Przyjęty do druku w „Literatura i Kultura Popularna” 2019.

TręBICKI, G. (2020). Merits of Fantastic Literature: A Proposal for Theoretical Framework. Złożony w „Literatura i Kultura Popularna”.

ZGorzelski, A. (1975). Konwencje gatunkowe i rodzajowe $w$ trylogii J.R.R. Tolkiena. W: Kreacje świata sensów. Szkice o współczesnej powieści angielskie (s. 53-84). Łódź: Lubelskie Towarzystwo Naukowe. 


\section{GRZEGORZ TRĘBICKI}

\section{AESTHETIC MERITS AND FORMAL EXPERIMENTS IN SECONDARY WORLD FANTASY}

The secondary world fantasy is quite justifiably regarded by scholars and critics as one of the most schematic, repetitive and commercial genres of contemporary non-mimetic literature. The present paper undertakes a preliminary discussion whether (and to what extent) this genre includes texts in which one can clearly discern a specifically understood aesthetic function (and whether this function can become a text's structural dominant). The article also addresses the question whether various formal experiments are possible in this kind of literature. 